(6) OPEN ACCESS

'Division of Epidemiology and Public Health, UK Centre for Tobacco and Alcohol Studies, University of Nottingham, Nottingham, UK

${ }^{2}$ Tobacco Control Research Group, Department for Health, University of Bath, 1 W 5.124, Claverton Down, Bath, UK

\section{Correspondence to}

Dr Alexander B Barker, Division of Epidemiology and Public Health, UK Centre for Tobacco and Alcohol Studies, University of Nottingham, Nottingham NG5 1PB, UK;

alexander.barker@nottingham. ac.uk

Received 10 April 2018 Revised 20 June 2018 Accepted 27 June 2018 Published Online First 13 August 2018

\title{
Content analysis of tobacco content in UK television
}

\author{
Alexander B Barker, ${ }^{\oplus}$ Kathy Whittamore, ${ }^{1}$ John Britton, ${ }^{1}$ Jo Cranwell ${ }^{2}$
}

\section{ABSTRACT}

Aims Exposure to audiovisual tobacco content in media is a risk factor for smoking in young people. While tobacco content in films has been extensively documented, content in mainstream television has received relatively little attention. We report an analysis of tobacco content in a sample of UK free-to-air primetime television broadcasts in 2015, and compare this with a similar analysis from 2010.

Design Content analysis of all programmes and advertisements or trailers broadcast on the five national UK free-to-air channels in the UK between 18:00 and 22:00 during three separate weeks in September, October and November 2015.

Setting Great Britain.

Participants None (media analysis only).

Measurements Occurrence of any tobacco, tobacco use, implied use, other tobacco reference/related objects and branding in every 1 min coding interval.

Findings Tobacco content occurred in $33 \%$ of all programmes and $8 \%$ of all adverts or programme trailer breaks. Actual tobacco use occurred in $12 \%$ of all programmes broadcast. Tobacco-related objects, primarily no smoking signs, occurred in $2 \%$ of broadcasts; implied tobacco use and tobacco branding were also rare. The majority of tobacco content occurred after the 21:00 watershed.

Conclusions These findings are virtually unchanged from our earlier analysis of programme content from 2010. Audiovisual tobacco content remains common in UK television programmes.

\section{INTRODUCTION}

Smoking uptake is a major threat to the health of children. Most adult smokers become regular smokers during childhood or adolescence, and those who continue to smoke sustain a loss of 1 day of life for every 4 days of smoking after the age of around $35 .{ }^{12}$ Preventing smoking uptake is therefore a public health priority.

There is strong evidence that exposure to tobacco imagery in films increases smoking uptake in adolescents, ${ }^{3}$ and this association is causal. ${ }^{4-6}$ However, while children spend more time watching television (TV) than films, the tobacco content of TV programming has received relatively little interest. An estimated 28 million British homes have at least one $\mathrm{TV}^{7}$ and in 2017 average viewing was 3 hours, 23 min per person per day. ${ }^{8}$

Tobacco advertising, promotion and sponsorship, including all TV advertising and paid product placement, is prohibited in the UK by the 2002 Tobacco Advertising and Promotion Act. ${ }^{9}$ However, tobacco imagery included in TV programmes, including trailers, for artistic or editorial purposes is exempt from the Act, instead covered by the Office of
Communications (OfCom) Broadcasting Code $\mathrm{C}^{10}$ (Section 1.10). Since 2005, ${ }^{11}$ the OfCom Broadcasting Code has protected under-18s by restricting depictions of tobacco use in programmes made for children and preventing the glamorisation of smoking in programmes broadcast before the 21:00 watershed (the time when TV programmes which might be unsuitable for children can be broadcast $^{12}$ ), or in programmes likely to be widely seen, heard or accessed by under-18s without editorial justification. However, $13 \%$ of $4-15$ year-olds in the UK view programmes after the 21:00 watershed $^{13}$ when programmes unsuitable for children are allowed to be broadcast, ${ }^{12}$ while an estimated $62 \%$ of $12-15$ year-olds have access to a TV in their bedroom, and $45 \%$ of children watch TV on devices such as tablets, allowing TV viewing without parental control. ${ }^{13}$

In a previous analysis of UK prime-time TV using content from $2010,{ }^{14}$ we found that tobacco content occurred frequently before the 21:00 watershed in both programmes and advertisement/trailer breaks, and that this exposed British child and adolescent audiences to smoking messages and tobacco branding. Since the previous analysis, the Tobacco Display Regulations ${ }^{15}$ have been introduced which prohibit tobacco point-of-sale displays. Point-of-sale displays were a regular occurrence in the previous analysis from $2010 .^{14}$ To determine whether the findings of the previous analysis remain representative we now report the results of a study of tobacco audiovisual content in all programmes and advertisements/trailers broadcast on all five UK freeto-air channels in 2015 and compare this with our findings from 2010.

\section{MATERIALS AND METHODS}

All programmes and advertisements/trailers broadcast on the five national UK free-to-air channels (BBC1, BBC2, ITV1, Channel 4 and Channel 5) were recorded during the peak viewing hours of 18:00 to 22:00, capturing data for the 3 hours before and 1hour after the Ofcom 21:00 watershed. All programmes and advertisements/trailers were recorded in three separate weeks (Monday to Sunday) in 2015, with a 4-week gap between each (21-27 September, 18-25 October, $16^{\text {th }}-$ $22^{\text {nd }}$ November). At the time of the study these five channels were the most watched channels in the $\mathrm{UK},{ }^{16}$ and remain so today, with the five channels accounting for $51 \%$ of all TV viewing. ${ }^{17}$ Two of these channels, BBC1 and BBC2, are public service channels with no commercial advertising, while ITV1, Channel 4and Channel 5 all feature commercial advertising. All recorded footage was viewed and coded using the $1 \mathrm{~min}$ interval period method as described in a previous analysis of TV content. ${ }^{14}$ The method includes recording the presence or 
absence of audio-visual tobacco content every $1 \mathrm{~min}$ in the following categories:

\section{Actual use}

Actual observed use of tobacco onscreen by any character, coded as cigarette, cigar, pipe or other (such as water pipe or chewing tobacco).

\section{Implied use}

Any inferred tobacco use without any actual use onscreen (eg, holding a cigarette without actual smoking or a comment about going for a cigarette), coded as verbal or non-verbal.

\section{Tobacco-related objects}

The presence of tobacco or tobacco related materials, coded by the type of appearance (including cigarette or other tobacco pack, matches, lighter, ashtray, no smoking or smoking area signs).

\section{Brand appearance}

The presence of clear and unambiguous tobacco branding, including cigarette or other tobacco packs, secondary advertising (advertisements appearing within other programmes) and branded merchandising.

\section{Any tobacco content}

Any of the above.

Tobacco appearances were recorded if they appeared onscreen in any $1 \mathrm{~min}$ coding period. Multiple instances of the same category in the same $1 \mathrm{~min}$ period were considered a single event; however, if two instances of different categories occurred this was recorded as two different events (eg, actual tobacco use and inferred use). The coding categories used were mutually exclusive, for example, if a person is seen smoking, this is coded as actual use rather than implied or tobacco-related object; however, if a scene featured both paraphernalia and implied use, both were recorded in the same $1 \mathrm{~min}$ interval. When the same appearance transitioned into a new $1 \mathrm{~min}$ period it was coded as two separate events as the appearance occurred in two $1 \mathrm{~min}$ intervals. One-third of the recorded footage was coded separately by two authors ( $\mathrm{AB}$ and $\mathrm{KW}$ ) to ensure accuracy and reliability in the coding method. Short trailers for other programmes are shown between programmes on BBC1 and BBC2, and both adverts and trailers between programmes on other channels. These have been coded as a single category of content, rather than code each individual advert/trailer these have been grouped together in each advertisement/trailer period between regular broadcast programming. Both the commercial (ITV, Channel 4, Channel 5) and non-commercial (BBC1, BBC2)

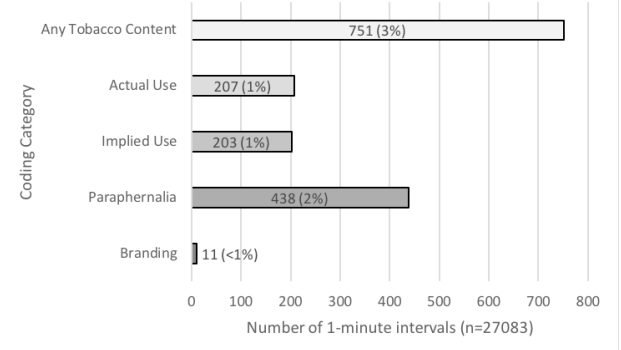

Figure 1 Number of 1 min intervals containing tobacco content coded by category. channels broadcast adverts for other programmes on the service during advert breaks; however, we coded advertisement breaks on non-commercial channels (trailers) separately to commercial channels (advertisements). We categorised the genre of each programme based on information from Box of Broadcasts ${ }^{18}$ and the researcher's discretion when genre not available. We also categorised whether any part of the programme occurred after the 21:00 watershed. Short trailers for other programmes are shown between programmes on $\mathrm{BBC} 1$ and $\mathrm{BBC} 2$, and both adverts and trailers between programmes on other channels. These have been coded as a single category of content. Descriptive analyses were conducted in IBM SPSS Statistics (V.23) and Microsoft Excel (2013).

\section{RESULTS}

We analysed 420 hours of footage including 611 programmes, 909 adverts and 211 trailers. A total of 27083 intervals of 1 min were coded, of which 22960 were from programmes, 3663 from adverts and 460 from trailers. The most frequent genres were News and Current Affairs, Documentaries and Soaps with a total of 137, 126 and 76 programmes, respectively. The genres which accounted for the highest broadcast time were Documentaries, News and Current Affairs and Entertainment, comprising 5482, 3573 and $2408 \mathrm{~min}$, respectively.

\section{Any tobacco content}

There were 291 broadcasts (programmes and adverts/trailers for other programmes) which included any tobacco content $(17 \%$ of all programmes), consisting of 751 intervals containing tobacco appearances (3\% of all intervals) (figure 1).

The channel containing the most tobacco appearances was Channel 5 (197 intervals; 26\% of any tobacco intervals) and the lowest was BBC2 (99 tobacco appearances; 13\% of total). The channel with the largest proportion of tobacco content was Channel 5 at $3 \%$ of all intervals (see table 1 ).

Of the 611 programmes broadcast, 201 (33\%) contained any tobacco content, occurring in 650 intervals of $1 \mathrm{~min}(3 \%$ of $1 \mathrm{~min}$ intervals in programmes). The genres containing the highest tobacco content were Animation (67\% of programmes), Comedy show $(57 \%$ of programmes) and Drama $(50 \%$ of programmes) (table 2).

Of the 1200 adverts/trailers analysed, 90 (8\%) contained any tobacco content, occurring in 101 of 4123 intervals of $1 \mathrm{~min}(2 \%$ of the total advert/trailer intervals). The $75 \%$ of programming in our sample broadcast before the 21:00 watershed contained $65 \%$ (486 intervals) of the 1 min intervals of observed tobacco appearances and references.

Table 1 Proportion of intervals containing tobacco by television channel

\begin{tabular}{ll} 
Channel & $\begin{array}{l}\text { Proportion of intervals containing tobacco } \\
\text { (intervals containing tobacco content/total } \\
\text { number of intervals coded) }\end{array}$ \\
\hline Overall & $3 \%(751 / 27083)$ \\
\hline BBC1 & $3 \%(153 / 5214)$ \\
BBC2 & $2 \%(99 / 5167)$ \\
ITV & $2 \%(113 / 5456)$ \\
Channel 4 & $3 \%(189 / 5547)$ \\
Channel 5 & $3 \%(197 / 5699)$ \\
\hline
\end{tabular}


Table 2 Percentage proportion of genres containing tobacco content

\begin{tabular}{|c|c|c|c|}
\hline Genre & $\begin{array}{l}\text { Total } \% \\
\text { (number of programmes containing } \\
\text { tobacco content/total number of } \\
\text { programmes) }\end{array}$ & $\begin{array}{l}\text { Before watershed \% } \\
\text { (number of programmes containing } \\
\text { tobacco content/total number of } \\
\text { programmes) }\end{array}$ & $\begin{array}{l}\text { After watershed } \% \\
\text { (number of programmes containing } \\
\text { tobacco content/total number of } \\
\text { programmes) }\end{array}$ \\
\hline Documentary & $47(57 / 126)$ & $40(33 / 82)$ & $55(24 / 44)$ \\
\hline News and Current Affairs & $34(47 / 137)$ & $35(47 / 135)$ & $0(0 / 2)$ \\
\hline Feature film & $43(6 / 14)$ & $33(3 / 9)$ & $60(3 / 5)$ \\
\hline Game show & $5(2 / 42)$ & $7(2 / 29)$ & $0(0 / 13)$ \\
\hline Sport & $7(1 / 14)$ & $0(0 / 8)$ & $17(1 / 6)$ \\
\hline Comedy & $57(8 / 14)$ & $50(5 / 10)$ & $75(3 / 4)$ \\
\hline Cookery & $14(4 / 28)$ & $14(4 / 28)$ & NA \\
\hline Drama & $50(17 / 34)$ & $38(5 / 13)$ & $57(12 / 21)$ \\
\hline Animation & $66(10 / 15)$ & $66(10 / 15)$ & NA \\
\hline Entertainment & $22(11 / 51)$ & $9(3 / 32)$ & $42(8 / 19)$ \\
\hline Religious & $0(0 / 1)$ & $0(0 / 1)$ & NA \\
\hline Educational & $0(0 / 1)$ & $0(0 / 1)$ & NA \\
\hline
\end{tabular}

NA, not applicable.

\section{Actual tobacco use}

Actual tobacco use appeared in 207 intervals (1\% of the total), in $76(12 \%)$ of programmes and $13(1 \%)$ of adverts/trailers. The highest proportion of tobacco use was cigarette smoking (164 intervals, $79 \%$ of all tobacco use), followed by pipe smoking (25 intervals, 12\%), cigar smoking (16 intervals, 8\%) and e-cigarette use (7 intervals, 3\%). One instance of tobacco use was unidentified. Tobacco use occurred in 14 out of the 20 genres and featured in 53\% and $36 \%$ of all Animation shows and Feature films, respectively. Most of the tobacco use in Animation featured in the show The Simpsons (occurring in 5\% of all Simpson's intervals). Most (52\%) of the intervals containing tobacco use were broadcast after the 21:00 watershed. Five Feature films $(36 \%)$ contained tobacco use, of which three were broadcast before the 21:00 watershed, and all five of which were classified by the British Board of Film Classification as suitable for viewing by children (one of them with no age restriction: U). Of the 207 intervals containing actual tobacco use, 104 (50\%) occurred before watershed.

\section{Implied tobacco use and tobacco-related objects}

Implied tobacco use was found in 203 intervals $(1 \%$ of all intervals) and in 118 of all broadcasts (programmes/adverts/ trailers combined). Smoking behaviour (eg, holding a cigarette) accounted for 163 intervals of implied use, 39 intervals contained a verbal mention of tobacco and in 10 intervals of other implied use. A total of 116 intervals (57\%) containing implied tobacco use occurred before the 21:00 watershed. Tobacco-related objects accounted for the most content appearing in 438 tobacco intervals ( $2 \%$ of total) and in 202 of all broadcasts. Up to 260 intervals $(66 \%)$ containing tobacco-related objects occurred before the 21:00 watershed. No smoking signs accounted for the most tobacco-related objects (see table 3).

\section{Tobacco brands}

There were 11 intervals (37 actual appearances) which contained tobacco branding, occurring in seven different programmes. Most of these appearances arose from cigarette packets or tobacco boxes shown during two news reports on illegal cigarettes (five intervals, $45.5 \%$ of the total branding intervals) or from appearances of the fictitious brand 'Laramie', which featured in 'The Simpsons' (five intervals, $45.5 \%$ of the total branding intervals). There was only one appearance during a TV programme in one interval (see table 4 for a breakdown of programmes and total number of appearances by each tobacco brand).

\section{Comparison to previous analysis}

In comparison to the previous content analysis of UK broadcast TV, the amount of intervals containing any tobacco content increased from 731 to 751 intervals (see table 5).

\section{DISCUSSION}

This study demonstrates that despite regulations restricting tobacco content being broadcast, tobacco imagery still occurs commonly on UK TV. While the majority of tobacco depictions occurred after the 21:00 watershed, tobacco depictions were observed both the watershed on the most popular TV channels. Although tobacco branding was rare and primarily comprised brands seen in news items about illicit tobacco or a fictional brand in The Simpsons. There is strong causal evidence that exposure to tobacco imagery increases smoking uptake in adolescents. ${ }^{3-6}$ It is likely that the amount of tobacco content shown on

\begin{tabular}{|c|c|}
\hline Tobacco-related object type & Total number of intervals \\
\hline Cigarette packet & 66 \\
\hline Matches & 6 \\
\hline Lighter & 57 \\
\hline Ashtray & 75 \\
\hline No smoking sign & 226 \\
\hline $\begin{array}{l}\text { Other (eg, signs or posters mentioning tobacco, } \\
\text { smoking mentioned as part of quit smoking adverts) }\end{array}$ & 100 \\
\hline
\end{tabular}


Table 4 Programmes and total number of appearances by each tobacco brand

\begin{tabular}{|c|c|c|c|c|c|c|}
\hline $\begin{array}{l}\text { Genre of } \\
\text { programme }\end{array}$ & $\begin{array}{l}\text { Title of } \\
\text { programme }\end{array}$ & Date programme aired & $\begin{array}{l}\text { Programme } \\
\text { aired before or } \\
\text { after watershed }\end{array}$ & $\begin{array}{l}\text { Number of } \\
\text { tobacco brands } \\
\text { shown in } \\
\text { programme }\end{array}$ & $\begin{array}{l}\text { List of tobacco brand } \\
\text { names shown in } \\
\text { programme (number of } \\
\text { appearances) }\end{array}$ & Description of brand appearance \\
\hline $\begin{array}{l}\text { BBC1 } \\
\text { (News) }\end{array}$ & News & 25 September 2015 & Pre & 2 & $\begin{array}{l}\text { Richmond (1); } \\
\text { Mayfair (1) }\end{array}$ & $\begin{array}{l}\text { Branding seen on packets of illegal cigarettes } \\
\text { in news item }\end{array}$ \\
\hline (Drama) & The Catch & 21 September 2015 & Pre & 1 & Drum (1) & $\begin{array}{l}\text { The skipper smokes a cigarette on the bridge } \\
\text { with a non-smoking deckhand. In the galley, a } \\
\text { branded tobacco packet can be seen. }\end{array}$ \\
\hline
\end{tabular}

UK broadcast TV in the current study leads to experimentation and uptake. The levels of tobacco imagery in the categories we coded are very similar to those reported in our earlier analysis of programming in $2010,{ }^{14}$ suggesting that UK prime-time TV is a constant source of exposure to tobacco imagery for young people. If the amount of tobacco content shown on TV remains consistent over time, tobacco use will remain normalised in society and continue to lead to subsequent adolescent use and uptake, while curtailing any trend towards decreasing smoking prevalence.

We coded only terrestrial channels since the majority of households have access to these channels and programmes aired on these channels consistently receive the highest viewing share in the UK. ${ }^{16}$ Given the large viewing audience of these channels, and the fact that the majority of viewing by $4-15$ year-olds in the UK occurs in early morning or early evening (19:00 to $21: 00),{ }^{13}$ it is very likely that children and young adults will have access to, and be viewing, the five main channels. However, we acknowledge that it is equally likely that children will have access to and view other channels. The sample method we used, three 1 -week periods, is potentially susceptible to seasonal influences on TV programmes and news stories; however, this is unlikely to have distorted our findings as the main sources of tobacco content were programmes which are aired throughout the year.

Table 5 Comparison of the number of 1 min intervals containing tobacco content in 2010 and 2015

\begin{tabular}{lll}
\hline & $\begin{array}{l}\text { Number of } 1 \mathrm{~min} \\
\text { intervals from the } \\
2010 \text { analysis }\end{array}$ & $\begin{array}{l}\text { Number of } 1 \mathrm{~min} \\
\text { intervals from the } \\
2015 \text { analysis }\end{array}$ \\
\hline Any tobacco content & 731 & 751 \\
\hline Actual tobacco use & 245 & 207 \\
\hline Implied tobacco use & 82 & 203 \\
\hline Tobacco-related objects* & 576 & 438 \\
\hline Tobacco branding & 27 & 11 \\
\hline${ }^{*}$ Combined 'Paraphernalia' and 'Other' categories from the 2010 data
\end{tabular}

We chose to code programmes broadcast between 18:00 and 22:00 since programmes shown in this time period are the most viewed throughout the week; however, without viewing figures it is impossible to know whether these channels were the most viewed for the 3 weeks coded. While there is strong evidence that exposure to advertising and/or other tobacco imagery increases subsequent use in adolescents, ${ }^{4-6}$ this study did not explore exposure through viewing figures or subsequent tobacco use and uptake following viewing UK prime-time TV.

Tobacco content in broadcast TV could act as a smoking cue, eliciting a smoking urge in the viewer, which could lead to reinforcing the smoking behaviour and relapse in former smokers. ${ }^{19-21}$ Consistent with earlier work, ${ }^{14}$ our coding of tobacco-related objects includes no smoking signage, while less likely to be a driver of smoking behaviour than imagery arising from actual smoking, could potentially be unintentionally acting as a smoking cue. ${ }^{22-24}$ As with other categories of tobacco content, the proportion arising from signage was very similar between the 2010 and present studies.

While the majority of tobacco depictions occurred after the 21:00 watershed, instances from all coding categories were shown before watershed. According to the OfCom Broadcasting Code 10 (Section 1.10), tobacco depictions are restricted before the 21:00 watershed unless editorially justified, to protect children and young people from potentially harmful imagery. ${ }^{12}$ In the current study, we observed almost 500 intervals of $1 \mathrm{~min}$ which contained tobacco content broadcast before watershed. Given that the majority of viewing by $4-15$ year-olds in the UK occurs in early morning or early evening (19:00 to $21: 00),{ }^{13}$ and there is a causal link between viewing tobacco content and subsequent use, ${ }^{3-6}$ the OfCom 21:00 watershed is currently not fulfilling its purpose.

This study demonstrates that tobacco content, including smoking, occurs frequently on UK prime-time TV in programmes which are likely to be viewed by young people, as such, this is likely to lead to experimentation and uptake among young children. We suggest that guidelines on tobacco content need to be 
revised and more carefully enforced to protect children from exposure to tobacco imagery and the consequent risk of smoking initiation.

\section{What this paper adds}

- Exposure to audiovisual tobacco content in media is a risk factor for smoking in young people.

- Advertising legislation and broadcasting regulations are in place to protect children from smoking imagery in UK television; however, a previous content analysis found that tobacco content is shown on prime-time UK television.

- Audiovisual tobacco content remains common in prime-time UK television programmes and is likely to be a significant driver of smoking uptake in young people.

- Guidelines on tobacco content need to be revised and more carefully enforced to protect children from exposure to tobacco imagery and the consequent risk of smoking initiation.

Contributors $A B$ led coding of data, supported the analysis of data and contributed to drafting the initial manuscript. KW contributed to coding of data. JC contributed to the analysis of data and drafting the manuscript. JB contributed to drafting the manuscript. All authors read and approved the final manuscript.

Funding This work was supported by the Medical Research Council [grant number MR/K023195/1] and the UK Centre for Tobacco and Alcohol Studies, with core funding from the British Heart Foundation, Cancer Research UK, Economic and Social Research Council and the Department of Health under the auspices of the UK Clinical Research Collaboration. The funders had no role in the study design, data collection and analysis, decision to publish or preparation of the manuscript.

Disclaimer The funders had no role in the study design, data collection and analysis, decision to publish or preparation of the manuscript.

Competing interests None declared.

Patient consent Not required.

Provenance and peer review Not commissioned; externally peer reviewed.

Data sharing statement Data are available from the authors on request.

Open access This is an open access article distributed in accordance with the Creative Commons Attribution Non Commercial (CC BY-NC 4.0) license, which permits others to distribute, remix, adapt, build upon this work non-commercially, and license their derivative works on different terms, provided the original work is properly cited, appropriate credit is given, any changes made indicated, and the use is non-commercial. See: http://creativecommons.org/licenses/by-nc/4.0/.

\section{REFERENCES}

1 Doll R, Peto R, Boreham J, et al. Mortality in relation to smoking: 50 years' observations on male British doctors. BMJ 2004;328:1519.

2 Pirie K, Peto R, Reeves GK, et al. The 21st century hazards of smoking and benefits of stopping: a prospective study of one million women in the UK. Lancet 2013;381:133-41.
3 Leonardi-Bee J, Nderi M, Britton J. Smoking in movies and smoking initiation in adolescents: systematic review and meta-analysis. Addiction 2016;111:1750-63.

4 U.S. Department of Health and Human Services. Preventing Tobacco Use Among Youth and Young Adults: A Report of the Surgeon General. Atlanta, GA: U.S. Department of Health and Human Services, Centers for Disease Control and Prevention, National Center for Chronic Disease Prevention and Health Promotion, Office on Smoking and Health, 2012.

5 U.S. Department of Health and Human Services. The Health Consequences of Smoking: 50 Years of Progress: A Report of the Surgeon General. Atlanta, GA: U.S. Department of Health and Human Services, Centers for Disease Control and Prevention, National Center for Chronic Disease Prevention and Health Promotion, Office on Smoking and Health, 2014.

6 National Cancer Institute. The Role of the Media in Promoting and Reducing Tobacco Use. Tobacco Control Monograph No. 19: U.S. Department of Health and Human Services, National Institutes of Health, 2008.

7 Broadcasters' Audience Research Board. Television ownership in private domestic households 1956-2017. 2017 http://www.barb.co.uk/resources/tv-ownership/ (14 Sep 2017)

8 Thinkbox. 2017 TV Viewing Report. 2018 https://www.thinkbox.tv/Research/NickableCharts/TV-viewing-and-audiences/2017-TV-viewing-report (10 Apl 18).

9 The Tobacco Advertising and Promotion Act 2002. Crown Copyright; 2002. https:// www.legislation.gov.uk/ukpga/2002/36/contents (25th Aug 2017).

10 Ofcom. The Ofcom Broadcasting Code (with the Cross-promotion Code and the On Demand Programme Service Rules). 2017 https://www.ofcom.org.uk/tv-radio-and-ondemand/broadcast-codes/broadcast-code (21 Aug 17).

11 Ofcom. The Ofcom Broadcasting Code. 2005 https://www.ofcom.org.uk/_data/ assets/pdf_file/0027/35856/broadcast-code-2005.pdf (12 Aug 2018).

12 Ofcom. What is the Watershed? 2013 https://www.ofcom.org.uk/tv-radio-and-ondemand/advice-for-consumers/television/what-is-the-watershed (21 Aug 2017)

13 TV Licensing. Telescope 2014. 2014 http://www.tvlicensing.co.uk/cs/Satellite? blobcol=urldata\&blobheadername 1=content-type\&blobheadervalue 1=application\% 2Fpdf\&blobkey=id\&blobtable=MungoBlobs\&blobwhere $=1370006221318 \&$ ssbinary $=$ true (14 Sep 2017).

14 Lyons A, McNeill A, Britton J. Tobacco imagery on prime time UK television. Tob Control 2014;23:257-63.

15 Tobacco Advertising and Promotion (Display and Specialist Tobacconists) (England) (Amendment) Regulations, 2012.

16 British Audience Research Board. Share by Broadcaster. 2017 http://www.barb.co.uk/ trendspotting/analysis/share-by-channel-2/ (21/09/2017).

17 Ofcom. PSB Annual Research Report 2017. 2017 https://www.ofcom.org.uk/_data/ assets/pdf_file/0019/103924/psb-annual-report-2017.pdf (02/10/17).

18 The British Universities and Colleges Film and Video Council. Box of Broadcasts. 2017 https://www.learningonscreen.ac.uk/ondemand/.

19 Killen JD, Fortmann SP. Craving is associated with smoking relapse: findings from three prospective studies. Exp Clin Psychopharmacol 1997;5:137-42.

20 Shiffman S, Engberg JB, Paty JA, et al. A day at a time: predicting smoking lapse from daily urge. J Abnorm Psychol 1997;106:104-16.

21 Niaura RS, Rohsenow DJ, Binkoff JA, et al. Relevance of cue reactivity to understanding alcohol and smoking relapse. J Abnorm Psychol 1988;97:133-52.

22 Lee S, Cappella JN, Lerman C, et al. Smoking cues, argument strength, and perceived effectiveness of antismoking PSAs. Nicotine Tob Res 2011;13:282-90.

23 Falcone M, Lerman C, Cappella JN, et al. No untoward effects of smoking cues in anti-smoking public service announcements. Drug Alcohol Depend 2013;133:279-82.

24 Harris JL, Pierce $M$, Bargh JA. Priming effect of antismoking PSAs on smoking behaviour: a pilot study. Tob Control 2014;23:285-90. 